\title{
Tuturan Langsung dan Tidak Langsung antara Penjual dan Pembeli di Pasar Tradisional Semarang
}

\author{
Sri Puji Astuti \\ Fakultas Ilmu Budaya,Universitas Diponegoro \\ Sripujiastuti0116@gmail.com
}

\begin{abstract}
The purpose of this research is to describe speech acts that occur between seller and buyer in traditional market. Data was obtained using the method of observation and recording techniques. After the data were collected, the data were analyzed by using pragmatic theory, especially speech acts. Based on the results of the research were found the types of speech acts used between sellers and buyers in traditional markets, namely literal direct speech acts, non-literal direct speech acts, literal indirect speech acts, and non-literal indirect speech acts. Literal direct speech acts were used by sellers and buyers because the seller's and the buyer's $l$ could be straightforward and clear, when the seller was angry with the buyer and the seller insinuated the other sellers.
\end{abstract}

Keywords: Speech acts, seller, buyer, and traditional market

\section{Intisari}

Tujuan penelitian ini adalah mendeskripsikan tindak tutur yang terjadi antara penjual dan pembeli di pasar tradisional Semarang. Data diperoleh dengan menggunakan metode simak dan teknik rekam dan teknik catat. Setelah data terkumpul, teori tindak tutur digunakan untuk menganalisis data. Berdasarkan hasil penelitian ditemukan jenis tindak tutur yang digunakan antara penjual dan pembeli di pasar tradisional yaitu tindak tutur langsung literal, tindak tutur langsung tidak literal, tindak tutur tidak langsung literal, dan tindak tutur tidak langsung tidak literal. Tindak tutur langsung literal digunakan oleh penjual dan pembeli karena penjual dan pembeli bertutur secara lugas, penjual marah kepada pembeli dan penjual menyindir penjual lainnya.

Kata Kunci: Tindak tutur, penjual, pembeli, dan pasar tradisional

\section{Pendahuluan}

Jika diamati, komunikasi yang terjadi di pasar tradisional berbeda dengan komunikasi yang terjadi di tempat lain. Proses jual beli di pasar tradisonal dapat dikatakan memiliki kekhasan. Jika diamati lebih lanjut penjual di pasar tradisional menggunakan cara yang berbeda-beda untuk menawarkan barang dagangannya. Ada penjual yang langsung menawarkan barang dagangannya dengan cara menonjolkan kualitas dagangannya misalnya dengan menggunakan kalimat Bu pisange ауи-ауи Bu. Ada juga yang menyapa pembeli misalnya Bu Rin mampir $B u !$ Ada juga penjual yang mengobral barang dagangannya misalnya beli dua gratis satu, dan sebagainya. Cara-cara tersebut dilakukan penjual untuk menarik calon pembeli. 
Pada waktu penjual dan pembeli bertransaksi tentunya mereka menggunakan media bahasa untuk berkomunikasi. Penjual dan pembeli ada yang menggunakan tuturan langsung ada juga yang tidak langsung. Berdasarkan latar belakang tersebut dalam makalah ini dibahas tidak tutur apa sajakah yang digunakan antara penjual dan pembeli di pasar tradisional Semarang.

Nadar (2009:20) mengklasifikasikan tindak tutur berdasarkan langsung dan tidak langsung. Di samping itu , tindak tutur juga dapat diklasifikasikan menjadi tindak tutur literal dan tidak literal. Tindak tutur langsung adalah tindak tutur yang terjadi apaabila penutur menggunakan kalimat sesuai dengan modusnya. Misalnya jika penutur bermaksud memerintah, atau memohon mitra tutur, penutur menggunakan kalimat imperatif. Jika penutur ingin menginformasikan sesuatu kepada mitra tutur, penutur menggunakan kalimat deklaratif, dan jika penutur ingin menanyakan sesuatu kepada mitra tutur, penutur menggunakan kalimat interogatif. Yang dimaksud tindak tutur tidak langsung adalah tindak tutur yang terjadi apabila penutur menggunakan modus tuturan tidak sesuai dengan maksud tuturan. Contoh kalimat deklaratif yang biasanya digunakan penutur untuk menginformasikan sesuatu kepada mitra, dalam tuturan digunakan untuk menyuruh (Wijana dan Muhammad Rohmadi, 2011:28). Pendapat tersebut didukung oleh Yule (1996:95) yang menyatakan bahwa tindak tutur langsung merupakan tindak tutur yang terjadi apabila antara struktur kalimat yang digunakan penutur dan fungsi kalimat ada hubungan sedangkan jika tidak ada hubungan antara stuktur kalimat yang digunakan penutur dan fungsi kalimat termasuk tindak tutur tidak langsung.

Wiyana, (1996:3) menyatakan bahwa tindak tutur literal terjadi apabila dalam bertutur penutur menggunakan kata-kata yang sama dengan maksud penutur. Arti literal Menurut Subroto (2011:37) adalah kata yang bermakna lugas atau bermakna sebenarnya. Sedangkan tindak tutur tidak literal terjadi apabila maksud penutur tidak sesuai dengan kata-kata yang dituturkan. Dengan kata lain penutur menggunakan kata-kata yang tidak sesuai dengan maksud tuturan.

Interseksi antara tindak tutur langsung dan tidak langsung dengan tindak tutur literal dan tidak literal diperoleh tindak tutur langsung literal, tindak tutur tidak langsung literal, tindak tutur langsung tidak literal, dan tindak tutur tidak langsung tidak literal (Wijana dan Muhammad Rohmadi, 2011:31-34) Tindak tutur langsung literal adalah tindak tutur literal yang terjadi apabila penutur menggunakan kalimat sesuai dengan modusnya dan penutur juga 
menggunakan kata-kata yang bermakna sebenarnya sesuai dengan maksud tuturan.Tindak tutur tidak langsung literal adalah tindak tutur yang terjadi apabila penutur menggunakan kalimat tidak sesuai dengan modusnya tatapi penutur menggunakan kata-kata bermakna sebenarnya sesuai dengan maksud tuturan. Tindak tutur langsung tidak literal adalah tindak tutur yang terjadi apabila penutur menggunakan kalimat sesuai dengan modusnya tetapi penutur menggunakan kata-kata yang tidak bermakna sebenarnya. Artinya kata-kata yang digunakan penutur tidak sesuai dengan maksud tuturan. Tindak tutur tidak langsung tidak literal adalah tindak tutur yang terjadi apabila penutur menggunakan kalimat tidak sesuai dengan modusnya dan makna kata yang digunakan penutur tidak sesuai dengan maksud tuturan.

\section{Metode Penelitian}

Metode yang digunakan dalam penelitian "Tuturan Langsung dan Tidak Langsung antara Penjual dan Pembeli di Pasar Tradisional Semarang" ini menggunakan metode simak. Menurut Sudaryanto (1993:133) dalam menggunakan metode simak dapat diterapkan dengan cara menyadap. Penyadapan yang dilakukan dalam penelitian ini yaitu menyadap percakapan antara penjual dan pembeli yang sedang bertransaksi di pasar tradisional Semarang. Metode sinak ini dilanjutkan dengan teknik rekam dan teknik catat. Selanjutnya teori tindak tutur digunakan untuk menganalisis data.

\section{Hasil dan Pembahasan}

Berdasarkan hasil penelitian, penjual dan pembeli di pasar tradisional Semarang menggunakan tindak tutur langsung literal, tindak tutur langsung tidak literal, tindak tutur tidak langsung literal, dan tindak tutur tidak langsung tidak literal.

\section{Tindak Tutur Langsung Literal}

Tindak tutur langsung literal ditemukan dalam tuturan penjual dan pembeli di pasar tradisioanal Semarang. Hal tersebut dapat dilihat dalam contoh berikut ini.

$\begin{array}{ll}\text { Penjual } & \text { : "Sandale Bu." } \\ & \text { 'Sandal Bu.' } \\ \text { Pembeli } & \text { : "Niki pinten?" } \\ & \text { 'Ini berapa?' } \\ \text { Penjual } & \text { : "Selangkung, Mbak." } \\ & \text { ' } \text { Dua puluh lima, Mbak.' } \\ \text { Pembeli } & \text { : "Kalih dasa inggih?" }\end{array}$




\begin{tabular}{|c|c|}
\hline & 'Dua puluh ya? \\
\hline \multirow[t]{2}{*}{ Penjual } & : "Pas Mbak" \\
\hline & 'Pas Mbak.' \\
\hline \multirow[t]{2}{*}{ Pembeli } & "Nomer 38?" \\
\hline & 'Nomor 38?' \\
\hline \multirow[t]{2}{*}{ Penjual } & : "Wonten." \\
\hline & "Ada." \\
\hline
\end{tabular}

Wacana di atas merupakan percakapan antara penjual sandal dan pembeli. Percakapan penjual dan pembeli dalam contoh di atas merupakan tindak tutur langsung literal karena dalam tuturan tersebut kalimat interogatif digunakan untuk bertanya. Jadi, penjual dan pembeli menggunakan kalimat sesuai denga modus tuturan. Pembeli menggunakan kalimat interogatif untuk menanyakan harga, ketersediaan barang sesuai yang diinginkan pembeli kepada penjual. Hal tersebut terdapat dalam kalimat niki pinte?, kalih dasa inggih?, nomer 38 ?. Begitu pula penjual menggunakan kalimat sesuai modusnya yaitu kalimat jawaban selangkung Mbak, Pas mbak, dan wonten.

$$
\begin{array}{ll}
\text { Pembeli } & \text { : "Cumi-cumine pira?" } \\
& \text { 'Cumi-cumi berapa?' } \\
\text { Penjual } & : \text { " } 45 ” \\
& \text { 'Empat puluh lima.' } \\
\text { Pembeli } & : \text { "Pilihke sing ngendhok ya!" } \\
& \text { "Pilihkan yang bertelur ya! } \\
\text { Penjual } & \text { : "Ya, sik ya tak nutukke iki disik!" } \\
& \text { "Ya sebentar saya selesaikan yang ini dulu." }
\end{array}
$$

Tuturan di atas terjadi antara pembeli dan penjual ikan. Tuturan dalam wacana di atas merupakan tindak tutur langsung literal karena baik penjual maupun pembeli menggunakan kalimat sesuai dengan modusnya. Pembeli menggunakan kalimat interogatif untuk bertanya. Hal tersebut terdapat dalam kalimat cumi-cumine pira? Pembeli menggunakan kalimat imperatif untuk menyuruh. Hal tersebut terdapat dalam kalimat pilihke sing ngendhok ya! Begitu pula penjual menggunakan kalimat imperatif untuk menyuruh pembeli menunggu giliran. Hal tersebut terdapat dalam kalimat ya, sik ya tak nutukke iki disik!

Pembeli : :Brambang seprapat pinten Pak?"

"Bawang merah seperempat berapa Pak?" 


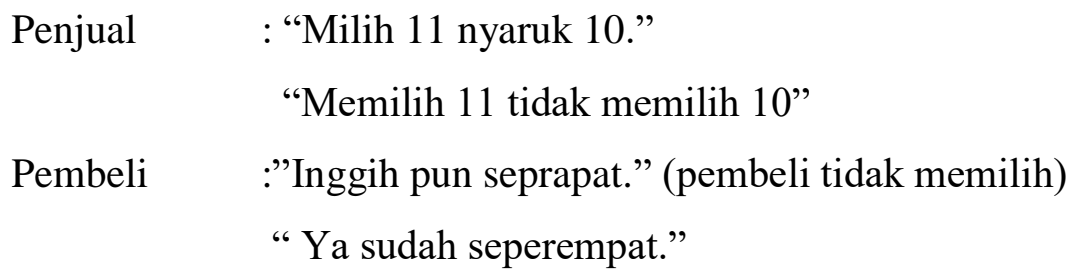

Tuturan di atas terjadi antara penjual bawang merah dan pembeli. Mula-mula pembeli menanyakan harga bawang merah. Hal tersebut terdapat dalam kalimat brambang seperapat pinten Pak? Pejual menjawab dengan memberikan alternatif pilihan kepada pembeli milih 11 nyaruk 10. Pembeli menyetujui harga yang diberikan penjual tetapi pembeli tidak memilih. Penjual memahami maksud pembeli sehingga penjual langsung menimbang bawang merah tanpa memilih bawang yang diinginkan. Tuturan di atas merupakan tindak tutur langsung literal karena penjual dan pembeli menggunakan kalimat sesuai dengan modusnya.Penjual dan pembeli juga menggunakan kata-kata yang bermakna sesuai dengan maksud tuturan.

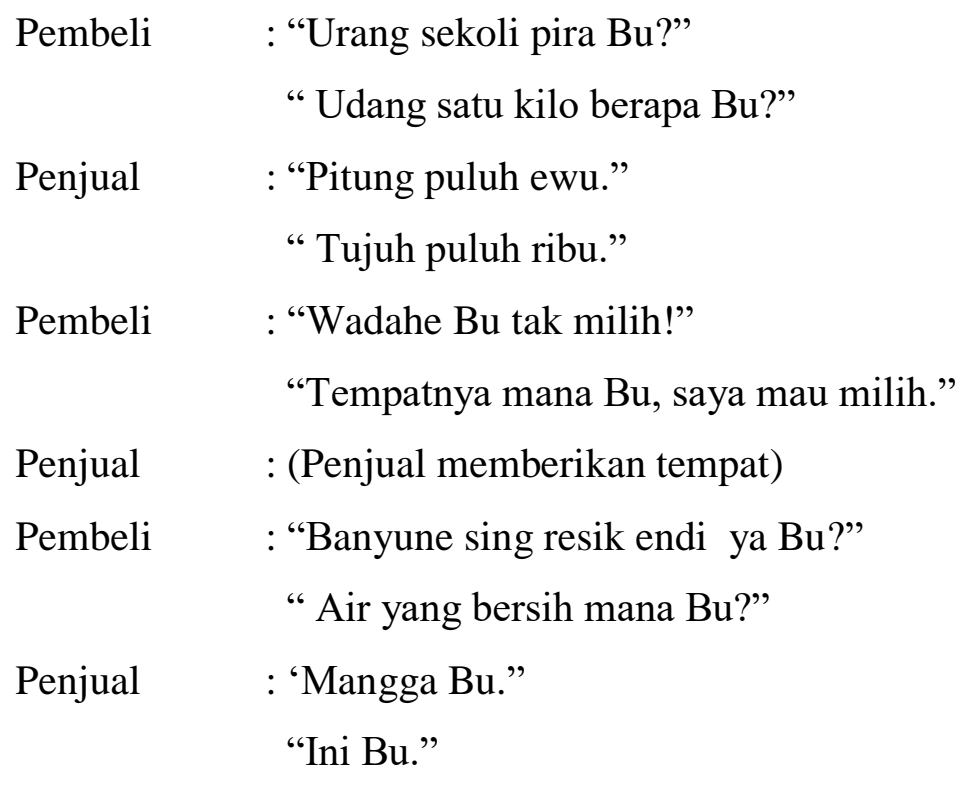

Tuturan di atas terjadi antara penjual ikan dan pembeli. Pembeli mau membeli udang satu kilogram. Setelah cocok dengan harga udang pembeli mau memilih udang. Oleh karena itu, pembeli minta tempat. Pembeli menggunakan kalimat interogatif untuk menanyakan harga udang dan untuk menanyakan air bersih untuk mencuci tangan. Hal tersebut terdapat dalam kalimat urang sekoli pira Bu? dan banyune sing resik endi ya Bu? Penjual menggunakan kalimat deklaratif untuk menginformasikan harga udang. Hal tersebut terdapat dalam kalimat pitung puluh ewu.Pembeli juga menggunakan kalimat imperatif untuk meminta tempat udang kepada penjual. Hal tersebut terdapat dalam kalimat Wadahe Bu tak milih! Jadi, penjual dan pembeli menggunakan modus kalimat yang sesuai dengan maksud tuturan. Artinya pembeli 
menggunakan kalimat interogatif untuk bertanya kepada penjual dan kalimat imperatif untuk meminta. Penjual menggunakan kalimat deklaratif untuk menginformasikan harga. Jadi, tuturan di atas merupakan tindak tutur langsung literal.

$$
\begin{array}{ll}
\text { Pembeli } & \text { : "Jagung pinten Bu?" } \\
& \text { " Jagung berapa Bu?" } \\
\text { Penjual } & \text { : "Pitung ewu." } \\
& \text { "Tujuh ribu." } \\
\text { Pembeli } & \text { : (pembeli langsung pergi) } \\
\text { Penjual } & \text { : 'Takon-takon tok ora tuku." } \\
& \text { "Tanya-tanya tidak beli." }
\end{array}
$$

Tuturan di atas terjadi antara pedagang sayur dengan pembeli. Mula-mula pembeli menanyakan harga jagung yang sudah dikemas dalam plastik. Setelah dijawab penjual, pembeli langsung pergi tanpa menawar. Pembeli menggunakan kalimat interogatif untuk menanyakan harga jagung. Hal tersebut terdapat dalam kalimat jagung pinten Bu? Sedangkan penjual menggunakan kalimat deklaratif untuk menginformasikan harga jagung. Akan tetapi, setelah pertanyaan pembeli dijawab oleh penjual, pemeli tidak merespon penjual. Pembeli langsung pergi. Oleh karena itu, penjual menuturkan takon-takon tok ora tuku. Adapun fungsi tuturan takon-takon tok ra tuku tersebut mengungkapkan kejengkelan atau kemarahan penjual kepada calon pembeli. Jadi, tuturan penjual dan pembeli dalam tuturan di atas merupakan tindak tutur langsung literal.

$$
\begin{aligned}
& \text { Penjual : "Cumi-cumi murah Bu." } \\
& \text { 'Cumi-cumi murah Bu." } \\
& \text { Pembeli : " Pira Bu?” } \\
& \text { 'Berapa Bu?' } \\
& \text { Penjual : " "45.” } \\
& \text { 'Empat puluh lima.' } \\
& \text { Pembeli : : Aku iki mau tuku 40. Pada entuk ra?" } \\
& \text { 'Aku tadi beli 40. Sama boleh?' } \\
& \text { Penjual :'Ya ora apa-apa." } \\
& \text { 'Ya tidak apa-apa' } \\
& \text { Pembeli : : Pilihke sing ngendhog ya!" } \\
& \text { ' Ya tidak apa-apa. Pilihkan yang bertelur ya!' }
\end{aligned}
$$


Penjual $\quad$ : (penjual memilih cumi-cumi yang bertelur)

"Bu ternyata ora ana sing ngendhog." Yen aku pilih ngomong jujur wae. Lha sing kuwi mau ngrepan ya embuh.”

'Bu ternyata tidak ada yang bertelur. Aku lebih baik jujur. Yang beli di depan tadi tidak tahu.'

Wacana di atas merupakan percakapan antara penjual ikan dan pembeli. Lokasi penjual ikan berhadapan dengan penjual ikan lainnya. Mula-mula pembeli membeli cumi-cumi pada penjual depannya dengan harga Rp40.000,00. Penjual sebelumnya juga memilihkan cumicumi yang bertelur. Setelah itu, pembeli menanyakan cumi-cumi kepada penjual lainnya. Ternyata di penjual yang kedua cumi-cumi yang bertelur tidak ada. Penjual kedua kemudian mengatakan Bu ternyata ora ana sing ngendhog. Yen aku pilih ngomong jujur wae. Lha sing kuwi mau ngrepan ya embuh. Tuturan tersebut merupakan tindak tutur langsung literal. Tuturan penjual kedua tersebut secara langsung menyindir penjual yang pertama. Penjual kedua dalam tuturan tersebut menggunakan kalimat deklaratif untuk menginformasikan bahwa cumi-cumi murah dan menginformasikan harga cumi-cumi. Hal tersebut terdapat dalam kalimat cumi-cumi murah Bu dan 45. Pembeli menggunakan kalimat deklaratif untuk menginformasikan bahwa pembeli sudah membeli cumi-cumi sebelumnya dengan harga empat puluh ribu. Hal tersebut terdapat dalam kalimat Aku iki mau tuku 40. Kemudian pembeli menggunakan kalimat interogatif untuk menanyakan harga cumi-cumi jika seperti harga cumi-cmi pedagang sebelumnya boleh apa tidak. Hal tersebut terdapat dalam kalimat pada entuk ra? Pembeli juga menggunakan kalimat imperatif untuk menyuruh penjual memilihkan cumi-cumi yang bertelur. Hal tersebut terdapat dalam kalimat pilihke sing ngendhog ya! Jadi, tuturan penjual dan pembeli dalam wacana di atas merupakan tindak tutur langsung literal.

$$
\begin{array}{ll}
\text { Pembeli } & \text { : "Bu urang sekilo!" } \\
& \text { 'Bu udang satu kilo. } \\
\text { Penjual } & \text { : 'Sing gedhe apa sing cilik Bu?" } \\
& \text { 'Y Yang besar apa yang kecil Bu? } \\
\text { Pembeli } & \text { : "Sing gedhe." } \\
& \text { 'Yang besar." }
\end{array}
$$

Wacana di atas merupakan percakapan antara pedagang ikan dan pembeli. Pembeli mengatakan $\mathrm{Bu}$ urang sekilo! merupakan kalimat imperatif yang berfungsi memerintah 
penjual untuk menimbangkan udang $1 \mathrm{~kg}$.Tuturan tersebut ditanggapi pedagang dengan menggunakan kalimat tanya yang digunakan untuk bertanya kepada pembeli mengenai yang dipilih udang yang besar atau kecil. Hal tersebut terdapat dalam kalimat sing gedhe apa sing cilik $B u$ ? Pembeli menggunakan kalimat deklaratif untuk menginforrmasikan bahwa udang yang dipilih yang besar. Hal tersebut terdapat dalam kalimat sing gedhe. Jadi, tuturan di atas merupakan tindak tutur langsung literal.

\section{Tindak Tutur Tidak Langsung Literal}

Tindak tutur tidak langsung literal ditemukan dalam tuturan penjual dan pembeli di pasar tradisional Semarang.

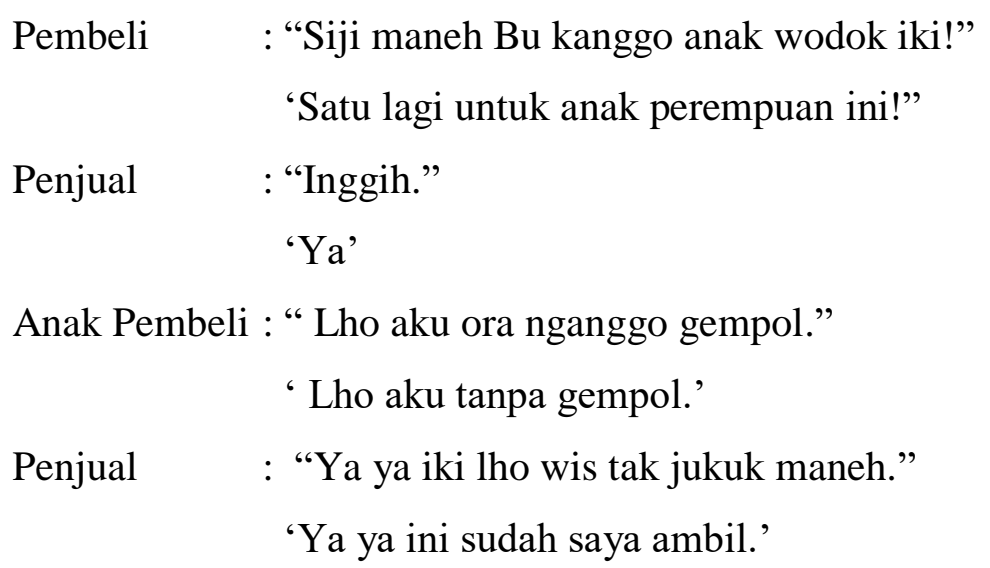

Wacana di atas merupakan percakapan yang terjadi antara penjual gempol dan pembeli yang membawa anak perempuan. Pembeli membeli tambahan gempol satu bungkus untuk anak perempuan yang ikut. Namun, ketika anak perempuannya melihat gempol dimasukkan ke dalam plastik, anak tersebut mengatakan lho aku ora nganggo gempol. Kalimat tersebut merupakan kalimat deklaratif yang berfungsi memerintah. Tuturan anak perempuan tersebut bermaksud agar gempol diambil lagi oleh penjual. Penjual memahami maksud anak perempuan tersebut sehingga penjual merespon dengan kalimat ya ya iki lho wis tak jukuk maneh. Jadi, tuturan lho aku ora nganggo gempol tersebut merupakan tindak tutur tidak langsung literal karena dalam tuturan anak perempuan tersebut menggunakan kata-kata sesuai maksud tuturan anak perempuan tetapi menggunakan modus yang tidak sesuai dengan maksud tuturan anak perempuan.

Penjual : :Wonten arta pas?" 


$\begin{array}{ll} & \text { : 'Ada uang pas? } \\ \text { Pembeli } & \text { : "Sekedap!” (Pembeli membuka dompet) } \\ & \text { 'Sebetar!' (Pembeli membuka dompet) } \\ & \text { :" Namung tiga likur ewu Bu.” } \\ & \text { 'Hanya dua puluh tiga ribu Bu' } \\ \text { Penjual } & \text { : "Mboten mapa-napa kurange mbenjang”' } \\ & \text { 'Tidak apa-apa kekurangannya besok' }\end{array}$

Wacana di atas merupakan percakapan antara penjual sayur dan pembeli. Pembeli harus membayar belanja dua puluh lima ribu rupiah. Pembeli membayar dengan uang seratus ribu rupiah. Karena penjual baru datang, penjual belum mempunyai uang kembalian. Oleh karena itu, penjual sayur minta pembeli membayar dengan uang pas. Akan tetapi, uang receh pembeli tidak mencukupi. Dalam wacana di atas penjual sayur menggunakan kalimat interogatif untuk meminta pembeli membayar dengan uang pas. Hal tersebut trdapat dalam kalimat wonten arta pas? Penjual sayur menggunakan modus kalimat tidak sesuai dengan maksud tuturannya.Tuturan penjual sayur ini merupakan tindak tutur tidak langsung. Karena kata-kata yang digunakan penjual sayur sesuai dengan maksud tuturannya maka tuturan tersebut merupakan tuturan literal. Jadi, penjual sayur dalam tuturan tersebut menggunakan tindak tutur tidak langsung literal.

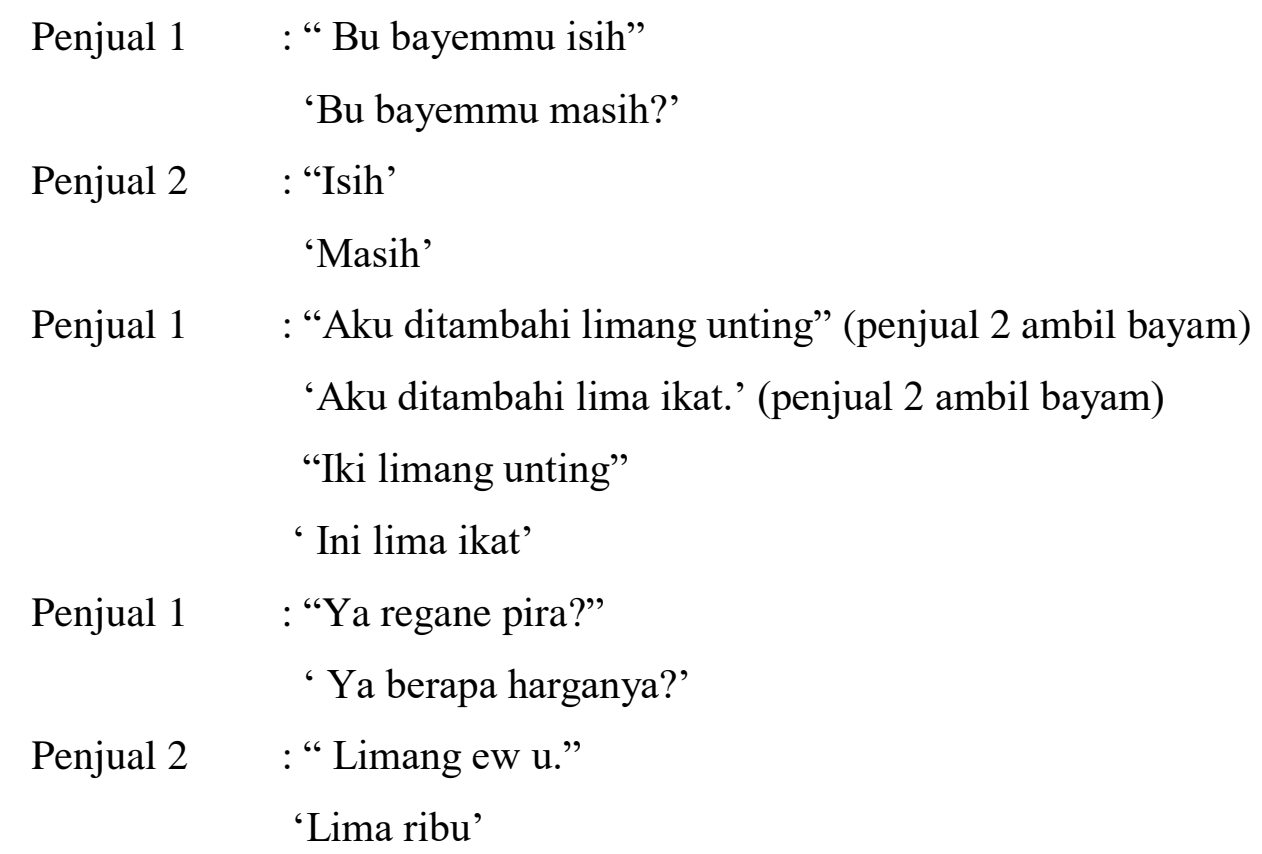

Penjual 1 : "Kok limang ewu aku ngedole terus pira?" 
'Kok lima ribu aku menjualnya terus berapa?'

Wacana di atas merupakan tuturan penjual sayur 1 dan penjual sayur 2. Sayur bayam penjual 1 habis. Oleh karena itu, penjual 1 minta tambahan bayam pada penjual dua. Namun, setelah penjual 2 pengambil bayam lima ikat penjual 1 baru menanyakan harga bayam. Harga bayam per ikat dari penjual 2 lima ribu rupiah. Padahal penjual 1 menjual bayam juga lima ribu rupiah. Oleh karena itu, penjual 1 menuturkan kok limang ewu aku ngedole terus pira? Tuturan penjual 1 merupakan tindak tutur tidak langsung literal karena penjual 1 menggunakan kalimat interogatif untuk meminta penurunan harga bayam kepada penjual 2 dan kata-kata yang digunakan penjual 1 sama dengan maksudnya.

\section{Tindak Tutur Langsung Tidak Literal}

$$
\begin{array}{cl}
\text { Pembeli } & \text { : } \\
& \text { 'Teri sing cilik-cilik ana Bu? } \\
\text { Penjual } & \text { : "Angine gedhe Bu." } \\
& \text { 'Anginnya besar Bu. }
\end{array}
$$

Wacana di atas merupakan percakapan yang terjadi antara pedagang ikan dengan pembeli. Pembeli menanyakan iklan teri kecil, akan tetapi pedagang menjawab angine gedhe $B u$. Tuturan penjual ikan tersebut merupakan tindak tutur langsung tidak literal karena dalam tuturan tersebut penjual menjawab dengan menggunakan kalimat deklaratif untuk menginformasikan bahwa anginnya besar. Hal tersebut terdapat dalam kalimat angine gedhe Bu.. Tuturan angine gedhe bermakna tidak ada teri kecil-kecil. Penjual ikan memberi jawaban dengan menyebutkan alasan kalau musim angin besar nelayan tidak berani ke tengah laut sehingga iklan teri tidak diperoleh nelayan. Jadi, tuturan penjual ikan merupakan tindak tutur langsung tidak literal.

$$
\begin{array}{cl}
\text { Pembeli } & \text { : 'Bandenge ayar Bu?" } \\
& \text { 'Ikan bandengnya baru Bu?' } \\
\text { Penjual } & \text { :'Wingi aku ora dodol." } \\
& \text { 'Kamarin saya tidak berjualan." }
\end{array}
$$

Wacana di atas merupakan percakapan yang terjadi antara pedagang ikan dan pembeli. Pembeli mananyakan ikan bandeng yang akan dibelinya baru atau tidak. Akan tetapi, jawaban yang diberikan penjual wingi aku ora dodol yang bermakna "bandeng yang dijual penjual bandeng baru'. Tuturan tersebut merupakan tindak tutur langsung karena penjual menggunakan kalimat deklaratif untuk menginfornasikan bahwa kemarin ia tidak berjualan. 
Adapun jawaban penjual ikan dengan menggunakan kalimat deklaratif aku wingi ora dodol merupakan tindak tutur tidak literal karena mengandung maksud bandeng yang dijualnya baru. Jadi, tuturan penjual ikan merupakan tindak tutur langsung tidak literal.

$\begin{array}{ll}\text { Pembeli } & \text { : 'Pisang pinten Bu?" } \\ & \text { 'Pisang berapa Bu?' } \\ \text { Penjual } & \text { : 'Selawe Bu." } \\ & \text { 'dua puluh lima Bu.' } \\ \text { Pembeli } & \text { : 'Rong puluh ya?" } \\ & \text { 'Dua puluh ya?' } \\ \text { Pemjual } & \text { : 'Tukune durung entuk." } \\ & \text { : 'Belinya tidak boleh,' }\end{array}$

Wacana di atas merupakan percakapan antara penjual pisang dengan pembeli. Pembeli menanyakan harga pisang satu sisir kepada penjual. Penjual menjawab harga pisang dua puluh lima ribu. Kemudian pembeli menawar pisang dua puluh ribu. Namun, jawaban yang diberikan penjual pisang tukune durung entuk. Penjual pisang menggunakan tuturan langsung karena penjual pisang menggunakan kalimat deklaratif untuk menginformasikan bahwa harga beli pisang di atas dua puluh tiga ribu rupiah. Hal tersebut terdapat dalam kalimat tukune durung entuk. Jawaban penjual pisang tukune durung entuk merupakan tuturan tidak literal karena kata-kata yang digunakan penjual tidak sesuai dengan maksud penjual. Tuturan penjual tukune durung entuk bermakna 'tidak boleh'. Jadi, tuturan penjual pisang tersebut termasuk tindak tutur langsung tidak literal

$$
\begin{array}{cl}
\text { Pembeli } \quad \text { : 'Bu jambune kok ayu-ayu ngene?" } & \\
\text { 'Bu jambunya kok cantik-cantik begini?' } & \quad \text { : 'Ya Nok, durung kulaan maneh. Sesuk barangne lagi teka." } \\
\text { 'YYa Nok, belum beli lagi. Besok barang baru datang.' }
\end{array}
$$

Wacana di atas merupakan percakapan yang terjadi antara penjual buah dengan pembeli. Pembeli melihat jambu biji kurang bagus, kemudian pembeli mengatakan Bu jambune kok ayu-ayu ngene? Tuturan pembeli tersebut merupakan tindak tutur langsung karena pembeli menggunakan kalimat interogatif untuk menanyakan jambu biji kepada penjual. Hal tersebut terdapat dalam kalimat Bu jambune kok ayu-ayu ngene?. Pertanyaan tersebut juga merupakan ungkapan kekecewaan pembeli melihat jambu biji yang kurang segar. Akan tetapi pembeli menggunakan kata ауи-ауи. Jadi, jambu ауи-ауи maksudnya jambu yang dijual jelek atau 
kurang segar. Hal tersebut didukung oleh jawaban penjual Ya Nok, durung kulaan maneh. Sesuk barangne lagi teka.Tuturan tersebut berarti penjual mengakui bahwa jambu biji yang dijual bukan barang baru. Jadi, tuturan pembeli dalam wacana di atas merupakan tindak tutur langsung tidak literal karena pembeli menggunakan modus kalimat sesuai dengan maksudnya tetapi pembeli menggunakan kata-kata yang tidak sesuai dengan maksudnya.

\section{Tindak Tutur Tidak Langsung Tidak Literal}

Tindak tutur tidak langsung tidak literal antara penjual dan pembeli di pasar tradisional Semarang dapat dilihat dalam contoh berikut ini.

Penjual : "Bu sayure ketimggalan Bu."

'Bu sayur tertinggal Bu.'

Wacana di atas dituturkan oleh penjual sayur yang berada di dekat tempat parkir sepeda motor. Penjual sayur menjual barang dagangannya di keranjang sepeda. Setiap ada perempuan yang lewat penjual sayur tersebut selalu menuturkan Bu sayure ketinggalan $\mathrm{Bu}$. Tuturan tersebut dapat memikat calon pembeli karena calon pembeli ketika mendengar tuturan tersebut secara spontan melihat barang dagangannya. Tuturan penjual sayur tersebut merupakan tindak tutur tidak langsung tidak literal karena kalimat tersebut merupakan kalimat deklaratif yang berfungsi menyuruh calon pembeli membeli barang dagangannya. Di samping itu, pemakaian kata ketinggalan dalam kalimat tersebut bukan berarti sayur yang dibeli pembeli tertinggal tetapi pedagang menyuruh calon pembeli membeli barang dagangannya. Jadi, tuturan pedangan sayur dalam wacana di atas merupakan tidak tutur tidak langsung tidak literal karena pedagang sayur menggunakan modus kalimat tidak sesuai dengan maksudnya dan pedagang sayur juga menggunakan kata-kata tidak sesuai dengan maksud tuturannya.

$\begin{array}{ll}\text { Pembeli } & \text { : "Bu urang sekilo." } \\ & \text { 'Bu udang satu kilo. } \\ \text { Penjual } & \text { : "Sing gedhe apa sing cilik Bu?" } \\ & \text { 'yang besar apa kecil?' } \\ \text { Pembeli } & \text { : "Sing gedhe." } \\ & \text { 'Yang besar." } \\ \text { Penjual } & \text { : "Dionceki resik Bu?" } \\ & \text { 'Dikupas bersih Bu?" } \\ \text { Pembeli } & \text { : "Buntute aja dibuang Bu!" }\end{array}$


"Ekornya jangan dibuang Bu!"

Penjual : (ganti memegang ikan pembeli yang lain)

Pembeli : : "Bu aku wis kawanan."

: 'Bu aku sudah kesiangan.'

Wacana di atas merupakan percakapan yang terjadi antara penjual ikan dan pembeli. Pembeli membeli udang besar. Pembeli menyuruh penjual mengupas udang, tetapi ekornya tidak dibuang. Penjuaal pun menyetujui keinginan pembeli. Namun, setelah menyetujui pembeli, penjual malah melayani pembeli yang lain. Oleh karena itu. pembeli mengatakan Bu aku wis kawanan,. Maksudnya, pembeli minta udangnya segera dikupas. Tuturan tersebut termasuk tindak tutur tidak langsung tidak literal karena pembeli menggunakan kalimat deklaratif untuk memerintah penjual agar segera mengupas udangnya. Di samping itu, pembeli juga menggunakan tindak tutur tidak literal karena kalimat $B u$ aku wis kawanan tidak bermakna sebenarnya. Jadi, tuturan pembeli dalam wacana di atas merupakan tindak tutur tidak langsung tidak literal.

Pembeli : :Pak tempe kripik kalih. Pilihke sing boten gosong!"

.Pak tempe kripik dua. Pilihkan yang tidak gosong!'

Penjual : "Sedoyo sampun digelar."

'Semua sudah di ditaruh situ."

Wacana di atas merupakan percakapan yang terjadi antara penjual kripik tempe dan pembeli. Pembeli membeli kripik tempe dua bungkus. Pembeli menyuruh penjual memilihkan tempe kripik yang tidak gosong. Namun, penjual menjawab sedoyo sampun digelar. Tuturan penjual merupakan tindak tutur tidak langsung tidak literal.Tuturan penjual kripik sedoyo sampun digelar merupakan kalimat deklaratif berfungsi memerintah pembeli memilih sediri kripik yang dijualnya karena semua barang dagangannya sudah ditaruh di atas meja. Jadi, sebetulnya penjual menyuruh pembeli untuk memilih barang yang diinginkan. Tuturan penjual keripik tempe merupakan tindak tidak langsung tidak literal karena penjual kripik menggunakan kalimat deklaratif untuk menyuruh pembeli dan kata-kata yang digunakannya tidak sesuai dengan maksud tuturanya.

\section{Simpulan}

Hasil penelitian menunjukkan bahwa tindak tutur yang digunakan antara penjual dan pembeli di pasar tradisional Semarang adalah tindak tutur lansung literal, tindak tutur tidak langsung literal, tindak tutur lansung tidak literal, dan tindak tutur tidak langsung tidak literal. Tindak 
tutur langsung literal digunakan oleh penjual dan pembeli di pasar tradisional karena dengan tindak tutur langung literal penjual dan pembeli dapat langsung memahami apa yang dituturkan. Artinya penjual dan pembeli langsung dapat mengerti maksud mereka. Berdasarkan hasil penelitian tindak tutur langsung literal ini lebih dominan jika dibandingkan dengan tindak tutur yang lainnya. Hasil penelitian juga menunjukkan bahwa tuturan langsung digunakan penjual ketika penjual marah kepada pembeli dan penjual menyindir penjual lainnya. Tindak tutur tidak langsung tidak literal digunakan penjual untuk memikat calon pembeli. Di samping itu, tindak tidak tutur tidak langsung tidak literal ini juga dapat menimbulkan penasaran calon pembeli.

\section{Daftar Pustaka}

Nadar, F.X.2009. Pragmatik dan Penelitian Pragmatik.Yogyakarta:Graha ilmu.

Subroto,Edi. 2011. Pengantar Studi Semantik dan Pragmatik. Surakarta:cakrawala Media.

Wijana, I Dewa Putu. 1996. Dasar-Dasar Pragmatik. Yogyakarta: Andi.

Wijana, I Dewa Putu dan Muhammad Rohmadi. 2011. Analisis Wacana Pragmatik kajian Teori dan Analisis. Surakarta:Yuma Pustaka

Yule, George. 1996. Pragmatik. Terjemahan Rombe Mustajab. Yogyakarta: Pustaka Pelajar 